DEPÓSITO LEGAL ZU2020000153

Esta publicación científica en formato digital

es continuidad de la revista impresa

ISSN 0041-8811

E-ISSN 2665-0428

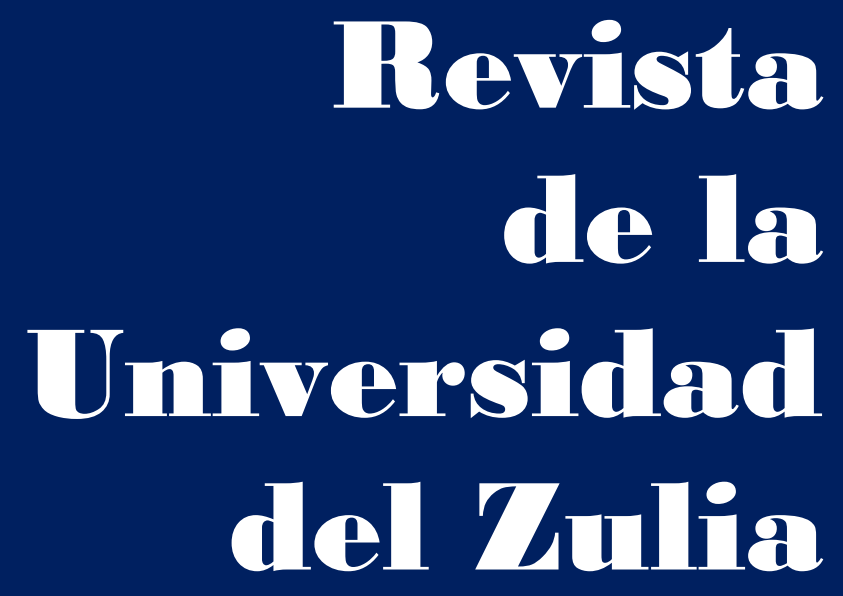

Fundada en 1947

por el Dr. Jesús Emrique Lossada

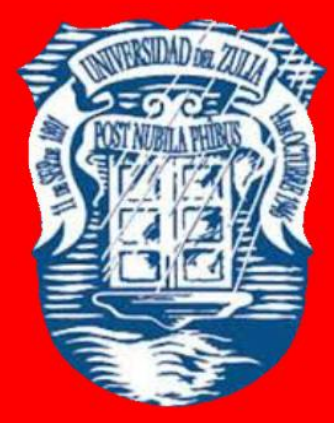

Ciencias

Sociales

y Arte

Año $12 \quad N^{\circ} 34$

Septiembre - Diciembre 2021

Tercera Época

Maracaibo-Veneruela 


\title{
Activities of the Peasant Land Bank in Penza province of Russia $(1883-1915)$
}

\author{
Roman V. Fedoseev * \\ Eduard D. Bogatyrev ** \\ Natalya A. Kisteneva ***
}

\begin{abstract}
The reform of 1861 not only freed the peasants from serfdom, but also led to radical economic changes in the agrarian sphere. The peasantry was involved in civil and legal relations associated with the purchase and sale of land. In order to assist land-poor peasants in the purchase of land, a specialized credit institution was created, which issued loans on favorable terms against the security of the acquired land plots. The purpose of this study is to identify the features of the activity of the Peasant Land Bank in the territory of the Penza province of Russia. Based on the materials of the Penza province, the main indicators of the activity of the Peasant Land Bank are analyzed, the dynamics of credit operations, the influence of its activities on the growth of land prices are considered, regional features of the processes under study are indicated. As a result of the study, it was concluded that the creation and operation of the Peasant Land Bank was an element of the government's agricultural policy aimed at creating peasant land tenure by providing loans to buy land from private owners.
\end{abstract}

KEY WORDS: bank; credit; financing; loans; agricultural credit; institution; land; history of Russia.

* Doctor of historical sciences, associate professor, professor of the department of state and legal disciplines of Mid-Volga Branch The All-Russian State University of Justice (RLA of the Ministry of Justice of Russia), Saransk, Russia. ORCID: https://orcid.org/0000-0001$\underline{7752-4513}$

** Doctor of historical Sciences, professor, professor of department of history of Russia, history and sociology Institute of Ogarev Mordovia State University, Saransk, Russia, https://orcid.org/0000-0003-2613-4958

*** Lecturer in the department of labor law and social welfare law of the Saransk Cooperative Institute (branch) of the Russian University of Cooperation, Saransk, Russia, https://orcid.org/0000-0002-4717-1259 


\section{Actividades del Banco de Tierras Campesinas en la provincia de Penza en Rusia (1883-1915)}

\section{RESUMEN}

La reforma de 1861 no sólo liberó a los campesinos de la servidumbre, sino que también condujo a cambios económicos radicales en la esfera agraria. El campesinado estaba involucrado en relaciones civiles y legales asociadas con la compra y venta de tierras. Con el fin de ayudar a los campesinos pobres en la compra de tierras, se creó una institución de crédito especializada, que emitió préstamos en condiciones favorables contra la seguridad de las parcelas de tierra adquiridas. El propósito de este estudio es identificar las características de la actividad del Banco de Tierras Campesinas en el territorio de la provincia de Penza de Rusia. Con base en los materiales de la provincia de Penza, se analizan los principales indicadores de la actividad del Banco de Tierras Campesinas, se considera la dinámica de las operaciones de crédito, la influencia de sus actividades en el crecimiento de los precios de la tierra, se indican las características regionales de los procesos en estudio. Como resultado del estudio, se concluyó que la creación y operación del Banco de Tierras Campesinas era un elemento de la política agrícola del gobierno destinada a crear la tenencia de la tierra campesina mediante la concesión de préstamos para comprar tierras a propietarios privados. PALABRAS CLAVE: banco; crédito; financiación; préstamos; crédito agrícola; institución; tierras; historia de Rusia.

\section{Introduction}

The reforms of the mid-19th century radically changed the agrarian sphere of prerevolutionary Russia. As a result, representatives of almost any class could become land owners, including the peasantry, who suffered from land scarcity. Most representatives of the peasantry could not afford to buy the required amount of land, which led to the development in the first decades of the post-reform lease relations, and subsequently the market for mortgage loans secured by land. Having become a participant in civil law relations related to the sale and purchase of land, the peasantry was able not only to process it, but also to acquire property. In economic terms, this estate was the weakest in pre-revolutionary Russia, low purchasing power limited the activity of the peasantry in the land market and prevented the solution of the pressing land issue. 
REVISTA DE LA UNIVERSIDAD DEL ZULIA. 3época. Año $12 \mathrm{~N}^{\circ}$ 34, 2021 Roman V. Fedoseev et al.// Activities of the Peasant Land Bank in Penza province... 483-51l DOI: http://dx.doi.org/10.46925//rdluz.34.27

The Peasant Land Bank was created as a specialized state lending institution to facilitate the purchase of land by the peasantry. The peasant land bank issued loans on favorable terms in cash secured by the land they bought from private owners, and subsequently from the bank itself. At the same time, this credit institution acted as an instrument of agrarian policy, functioning in close connection with the noble bank, another estate bank, it gradually began to realize to a greater extent the interests of large landowners, buying out land plots from them at fixed prices, thereby contributing to an increase in land prices and undermining the already low purchasing power of the peasantry.

The purpose of this study is to identify the features of the activity of the Peasant Land Bank in the territory of the Penza province of Russia during the period under review.

\section{Materials and methods}

Consideration of the main indicators of the activity of the Peasant Land Bank on the territory of the Penza province was carried out on the basis of a comprehensive analysis of the reports of this credit institution for the period from 1883 to 1915. The processing and analysis of this kind of sources predetermined the use of a number of historical and economic methods: quantitative analysis, statistical, comparative historical, systemic, etc.

The issues of the creation and functioning of the Peasant Land Bank in the second half of the 19th century - the beginning of the 20th century arouses quite a lot of research interest to this day; at the same time, the attention of scientists is focused mainly on the all-Russian indicators, the activities of the Peasant Bank in the territory of certain regions and provinces are covered much less often. The coverage of the main indicators of the bank's activities in the Penza province was carried out for the first time, which cannot but arouse interest among researchers who are not indifferent to the history of Russia.

\section{Analysis of results}

After the reforms of 1860 - 1870, land becomes a full-fledged object of sale and purchase, and all estates were included in the system of these relations, including the peasantry, which received personal freedom, albeit limited, according to the Manifesto "On the All-Merciful Granting of Serfs Rights the state of free rural inhabitants, and the structure of their life"(On the all-merciful granting, 1861) dated February 19, 1861, and the Regulations 
REVISTA DE LA UNIVERSIDAD DEL ZULIA. 3época. Año $12 \mathrm{~N}^{\circ}$ 34, 2021 Roman V. Fedoseev et al.// Activities of the Peasant Land Bank in Penza province... 483-51l DOI: http://dx.doi.org/10.46925//rdluz.34.27

on the peasants who have emerged from serfdom adopted on its basis (Regulations on the peasants, 1861). In particular, the Regulation fixed for the peasants a temporary obligation "for the allotted allotment ... to serve, in favor of the landlords ... obligations: work or money" (Regulations on the peasants, 1861), this led to the involvement of peasants in the system of civil law relations, from that moment they could acquire real estate, conclude transactions, including with the ground. In addition, as a result of the reform, peasant holdings were significantly reduced, which caused a significant demand for land. One of the means of solving the "land issue" was the provision of a soft loan for the purchase of land, for which the Peasant Land Bank was created, the main purpose of which was to provide peasants with long-term loans on favorable terms to assist in the purchase of land from private owners "in cases where landowners want to sell, and the peasants to buy them" (Regulations on the peasant, 1882).

Thus, the creation of the Peasant Land Bank was caused by a number of reasons, primarily the shortcomings of the Regulation on peasants who emerged from serfdom on February 19, 1861 (Regulations on the peasants, 1861). In accordance with the Regulation, it was possible to take the land owed in full, but with a ransom, or a quarter of it, but free; the presence of cuts, the traditional system of duties, prompting the landowners to strive for the peasants to buy out a smaller allotment, since in this case the redemption amount per tithe increased accordingly, as well as a number of other circumstances led to a peasant land shortage. In addition, the landlessness of the peasantry was facilitated by natural population growth, so according to A.N. Zak, the rural male population in all categories of peasants was equal to 23.1 million souls in 50 provinces of European Russia in 1860, 31.5 million souls in 1880, correspondingly, the per capita allotment for one male peasant soul decreased (Zak Peasant, 1911).

In general, establishing the Peasant Land Bank, the government pursued two goals: the development of land tenure among land-poor peasants, as well as assistance to the peasants who were stronger in terms of property, as an element more adapted to the perception of higher agricultural practices and, for purely political reasons, for the sake of creating a class of "strong peasantry", as an element of a more conservative, therefore, and more suitable for the dominant system of government at that time (Richter Agrarian, 1917). 
REVISTA DE LA UNIVERSIDAD DEL ZULIA. 3época. Año $12 \mathrm{~N}^{\circ}$ 34, 2021 Roman V. Fedoseev et al.// Activities of the Peasant Land Bank in Penza province... 483-51l DOI: http://dx.doi.org/10.46925//rdluz.34.27

According to the Regulations of 1882, the Peasant Land Bank was "a government agency under the authority of the Minister of Finance". The bank's activities gradually spread "to certain areas of the Empire, by agreement of the ministers of finance and internal affairs" (Regulations on the peasant, 1882).

Initially, the Bank's actions extended to the territory of European Russia, with the exception of the Kingdom of Poland and the Baltic provinces. The Kingdom of Poland was included in the scope of the bank from 1890, and the Transcaucasus and the Baltic provinces from 1906 (Proskuryakova, 1993). Every year the territory of its activity expanded and 52 local branches of the Peasant Bank functioned by the end of 1915, its activities extended to 68 provinces and 5 overgrowths of the European and Asian parts of Russia (however, military operations against Germany and Austria-Hungary forced the evacuation of branches from the provinces Kingdom of Poland, as well as Kholmsk, Courland, Kovno, Grodno, Livonia, Vilna, Minsk and Podolsk provinces to the central cities of the Empire: Moscow, Ryazan, Penza, Oryol, Voronezh, Chernigov, Tambov, Simbirsk and Saratov) (Report of the Peasant Land Bank, 1915).

The Penza branch of the Peasant Land Bank was opened on January 31, 1884 for lending to peasants for the purchase of land and was directly subordinate to the Council of the Bank. The bank branch consisted of: its manager, appointed by the Minister of Finance, one member, appointed by the governor, and two members, elected by the provincial zemstvo assembly. In addition to the aforementioned persons, the staff in the distance included a significant number of service personnel. The list of employees in 1908 in the Penza branch of the Peasant Land Bank included: 9 permanent members, 3 clerks, 3 clerk assistants, 4 accountants, 3 accountant assistants, 1 forestry scientist, 1 forest technician, 1 scribe in the civil service and 55 scribes "for free hire" (State Archives of the Penza Region). As can be seen from the number of employees, the Penza branch of the bank was a fairly developed structure, which was due to a large number of cases on the issuance of loans. The Penza branch of the Peasant Land Bank was opened on January 31, 1884 for lending to peasants for the purchase of land and was directly subordinate to the Council of the Bank. The bank branch consisted of: its manager, appointed by the Minister of Finance, one member, appointed by the governor, and two members, elected by the provincial zemstvo assembly. In addition to the aforementioned persons, the staff in the distance included a significant number of service 
REVISTA DE LA UNIVERSIDAD DEL ZULIA. 3época. Año $12 \mathrm{~N}^{\circ}$ 34, 2021 Roman V. Fedoseev et al.// Activities of the Peasant Land Bank in Penza province... 483-51l DOI: http://dx.doi.org/10.46925//rdluz.34.27

personnel. The list of employees in 1908 in the Penza branch of the Peasant Land Bank included: 9 permanent members, 3 clerks, 3 clerk assistants, 4 accountants, 3 accountant assistants, 1 forestry scientist, 1 forest technician, 1 scribe in the civil service and 55 scribes "for free hire." As can be seen from the number of employees, the Penza branch of the bank was a fairly developed structure, which was due to a large number of cases on the issuance of loans. In particular, according to Article 8 of the 1892 Regulation, employees in the branches carried out: receiving applications from those wishing to buy land with the assistance of a bank, procedures for appraising land plots, assisting sellers and buyers in making transactions, issuing loans authorized by the Council of the bank, applying for benefits and installments payments in case of force majeure; measures to collect overdue debts (Regulations on the peasant, 1882). The charter, approved on November 27, 1895 and terminated the provision of 1882, additionally entrusted the bank branches with the duties "for the economic administration of the estates" belonging to the bank, for "drawing up proposals for the sale of the bank's lands. Moreover, the list of subjects of management of the branches was not exhaustive in the Charter of 1895, unlike the provision of 1882, in particular, the branches were entrusted with "the fulfillment of other duties assigned to them by the Charter, the Order and special orders of the Minister of Finance, the Council and the Bank Manager" (Charter of a peasant land bank, 1895).

Loans were issued to individual peasants, rural societies and partnerships, subject to mutual guarantees. Preference was given to the first two before 1906, and to individual householders after the start of the Stolypin agrarian reform. Initially, only persons belonging to the peasant class could use the services of the bank. Subsequently, at the request of the bank, the circle of those using the services of the bank was expanded by representatives of other estates engaged in agriculture. The bank's board was charged with managing the estates remaining with the bank and selling them. The loan term was originally set from 24 years and 6 months to 34 years and 6 months (Regulations on the peasant, 1882), and from 13 years to 51 years and 9 months from 1895 (Charter of a peasant land bank, 1895).

In general, three significantly different periods can be distinguished in the activities of the Peasant Land Bank: 1) 1883 - 1895; 2) 1896 - 1905; 3) 1906 - 1917. This was noticed by A.N. Zach in his work, published in 1911 (Zak Peasant, 1911), i.e. when the bank continued to 
REVISTA DE LA UNIVERSIDAD DEL ZULIA. 3época. Año $12 \mathrm{~N}^{\circ}$ 34, 2021 Roman V. Fedoseev et al.// Activities of the Peasant Land Bank in Penza province... 483-51l DOI: http://dx.doi.org/10.46925//rdluz.34.27

function. The same periods are distinguished by N.A. Proskuryakov (Proskuryakova, 1993) and S.A. Frolov (Frolov, 2004).

It should be noted that the periodization of the bank's activities looks very reasonable. Three periods are traced in the activity of the credit institution under consideration, according to the periodization adopted in the scientific literature. The first covers the activities of the bank on the basis of the Regulation of May 18, 1882 (Regulations on the peasant, 1882), when it was given the right to perform intermediary functions in the purchase of land by peasants from private owners, issuing loans for this purpose against the security of the purchased land. In fact, the bank began issuing loans on April 10, 1883, after, in addition to Regulation 1882, the rules "On the procedure for the commission of serf acts for the purchase of land plots acquired with the assistance of the Peasant Land Bank" were adopted (On the procedure for the commission, 1883). The second period includes the activities of the Peasant Bank according to the rules approved by the Charter of November 27, 1895 (Charter of a peasant land bank, 1895), which gave him the right to acquire land from private owners at the expense of his own capital for the purpose of their further resale to peasants. The amount of equity capital was limited to 50 million rubles, which was enshrined in clause 8 of the Manifesto of November 14, 1894 (On the most mercifully, 1894). The third period is associated with the implementation of the Stolypin agrarian reform, in which he was assigned one of the most important roles. In accordance with the Manifesto of November 3, 1905, the Peasant Bank had the opportunity to "more successfully help land-poor peasants in expanding the purchase of their land holdings by increasing the bank's funds and establishing more favorable rules for issuing loans" (On improving the welfare, 1905). On the same day, a decree was adopted that removed the restrictions on the size of the bank's equity capital: "to replenish the bank's equity capital, sell certificates as the actual need for amounts for the bank to purchase land" (On facilitating the task, 1905). It should be noted here that traditionally the third period of the bank's activity is associated with the beginning of the Stolypin transformations, although the reforms began with the adoption of the Decree of November 9, 1906 (On the addition of some, 1906), which legalized the withdrawal of peasants from the community, at the same time the expansion of the bank's activities was approved by the aforementioned Manifesto and Decree. Thus, if the Charter of 1895 limited 
REVISTA DE LA UNIVERSIDAD DEL ZULIA. $3^{a}$ época. Año $12 \mathrm{~N}^{\circ} 34,2021$ Roman V. Fedoseev et al.// Activities of the Peasant Land Bank in Penza province... 483-51l DOI: http://dx.doi.org/10.46925//rdluz.34.27

the volume of purchased land to the size of its own capital, then during the period of the agrarian reform these restrictions were actually lifted.

The activities of the Peasant Land Bank on the territory of the Penza province will be considered by us on the basis of the periodization described above.

During the period when the Peasant Land Bank was created, long-term credit was viewed as an important measure that could bring peasants out of the difficult situation in which they found themselves after the reforms of the mid-19th century.

The peasant land shortage caused a significant interest on the part of the peasants in the possibility of buying land through the intermediary of the bank in question in the first years of its activity. Thus, 692 loans in the amount of 9,529,369 rubles were issued throughout the entire territory of the bank's activity in 1884, 210,047 dessiatines of land were pledged; 1,180 loans in the amount of 13,761,978 rubles secured by 318,002 dessiatines of land were issued in 1885; 1,209 loans in the amount of 11,148,850 rubles secured by 294,688 dessiatines of land were issued in 1886. In the future, there is a gradual decline in lending to the Peasant Land Bank, the peak of which was reached by 1889, when only 922 loans were issued in the amount of 3,692,134 rubles secured by 156,347 dessiatines of land, after which the indicators under consideration stabilized. In total, for the period from 1883 to 1895, 14,925 loans were issued on the territory of Russia, on the security of 2,411,865 dessiatines of land in the amount of 82,359,684 rubles. You can see practically the same processes in the Penza province: there was a great demand for credit in 1884 and 1885, 16 and 27 loans were issued in the amount of 382,060 and 447,320 rubles, secured by 4,284 and 6,668 dessiatines of land, respectively; then a noticeable decline in indicators, the peak of which fell on 1893, in contrast to the country as a whole, when only 2 loans were issued secured by 166 dessiatines of land in the amount of 3,575 rubles. In total, during the period under study, 81 loans were issued in the amount of 1,161,880 rubles in the territory of the Penza province, 18,410 dessiatines of land were pledged. At the same time, the share of the province in question in the total volume of the bank's activities for the period under study was extremely insignificant and amounted to only $0.5 \%$ of the total number of loans issued, $0.8 \%$ of all land pledged in the bank and $1.4 \%$ of the total loan amount (Table l). 
REVISTA DE LA UNIVERSIDAD DEL ZULIA. 3época. Año $12 \mathrm{~N}^{\circ}$ 34, 2021 Roman V. Fedoseev et al.// Activities of the Peasant Land Bank in Penza province... 483-5ll DOI: http://dx.doi.org/10.46925//rdluz.34.27

Table 1. Loans issued by the Peasant Land Bank in Russia and the Penza province in the period from 1883 to 1895 (Report of the Peasant Land Bank 1884-1895, 1915).

\begin{tabular}{|c|c|c|c|c|c|c|}
\hline \multirow{2}{*}{ Years } & \multicolumn{3}{|c|}{ Penza province } & \multicolumn{3}{c|}{ Total across Russia } \\
\cline { 2 - 7 } & Number loans & $\begin{array}{c}\text { Amount of } \\
\text { dessiatines } \\
\text { of land }\end{array}$ & $\begin{array}{c}\text { Loan amount, } \\
\text { ruble }\end{array}$ & $\begin{array}{c}\text { Number } \\
\text { of loans }\end{array}$ & $\begin{array}{c}\text { Amount of } \\
\text { dessiatines } \\
\text { of land }\end{array}$ & $\begin{array}{c}\text { Loan amount, } \\
\text { ruble }\end{array}$ \\
\hline 1883 & 0 & 0 & 0 & 69 & 18237 & 861163 \\
\hline 1884 & 16 & 4284 & 382060 & 692 & 210047 & 9529369 \\
\hline 1885 & 27 & 6668 & 447320 & 1180 & 318002 & 13761978 \\
\hline 1886 & 8 & 2139 & 110650 & 1209 & 294688 & 11148850 \\
\hline 1887 & 5 & 2319 & 122695 & 1035 & 219480 & 7495197 \\
\hline 1888 & 4 & 248 & 9520 & 1057 & 190463 & 5133539 \\
\hline 1889 & 3 & 633 & 21450 & 922 & 156347 & 3692134 \\
\hline 1890 & 4 & 439 & 15910 & 1203 & 172138 & 4519209 \\
\hline 1891 & 2 & 220 & 10500 & 1186 & 162940 & 4438667 \\
\hline 1892 & 2 & 192 & 13350 & 1343 & 148018 & 4554647 \\
\hline 1893 & 2 & 166 & 3575 & 1488 & 157298 & 5175814 \\
\hline 1894 & 4 & 611 & 12350 & 1680 & 180965 & 5743882 \\
\hline 1895 & 4 & 491 & 12500 & 1861 & 183242 & 6305235 \\
\hline Total & 81 & 18410 & 1161880 & 14925 & 2411865 & 82359684 \\
\hline
\end{tabular}

The significant reduction in the bank's lending operations, both in Russia as a whole and in the Penza province, can be explained by several reasons. First of all, this is the fall in grain prices due to the agrarian crisis of the early 1880s, which led to a gradual decline in the solvency of the peasantry. Secondly, the beginning of the operation of the Noble Land Bank in 1885 , the volume of activity of which immediately reached an impressive size, which is explained by the desire of the landowners to transfer their estates mortgaged in private banks to the Noble Bank, which provided more favorable credit conditions (Fedoseev and others, 2019). In addition, as D.I. Richter "the nobles had the opportunity to acquire a loan on favorable terms against their collateral without liquidating their lands" (Richter Agrarian, 1917). Thirdly, the excessive activity of the Peasant Bank, which put up for sale a large amount of land in the first years of its activity due to the significant demand for it from the peasantry.

The next payments in the amount of 77,961 rubles 51 kopecks should have been received in 1887, in fact, 38,217 rubles 27 kopecks were paid. Underpayment of payments amounted to $50.1 \%$, and if we take the entire territory of the bank's activity, then the situation was worse only in the Orenburg province, where the underpayment was $72.3 \%$ (State Archives of the Penza Region). All this led to an increase in arrears, and Penza province was 
REVISTA DE LA UNIVERSIDAD DEL ZULIA. 3época. Año $12 \mathrm{~N}^{\circ}$ 34, 2021 Roman V. Fedoseev et al.// Activities of the Peasant Land Bank in Penza province... 483-51l DOI: http://dx.doi.org/10.46925//rdluz.34.27

one of the leaders in this indicator. As noted in the bank's report for 1890, "the reason for the accumulation of these arrears is very varied; one of the more important between them, covering a significant part of Russia, must be considered a number of poor harvests, as well as the fall in prices for agricultural products" (Report of the Peasant Land Bank, 1890). The above circumstances naturally influenced the activities of the Bank's Council, which was forced, due to the growth of arrears and the resulting need to sell many land plots, to be particularly cautious about approving new requests from the bank's branches for loan permission.

Another important factor was that the bank's activity in the first two periods of its operation was focused on the issuance of loans to rural societies and partnerships, which were bound by a mutual guarantee on the issue of the payment of regular payments, on the contrary, the issuance of loans to individual peasants was a single phenomenon. Initially, the government, although it was determined to improve the provision of land to peasants, was focused on preserving communal land tenure, therefore the Peasant Bank provided more favorable credit conditions to rural societies and partnerships than to individual households (Proskuryakova, 1993). Beyond the general direction of government policy, the bank's focus on "collective" clients is partly due to purely practical reasons. It is difficult to find small plots of land at an affordable price in order to subsequently meet the demand from individual peasants (Ruziyeva and others, 2019). It is also obvious that the larger the size of the purchased plot, the lower the average price of 1 dessiatines of land, further reselling the land to the peasants in small shares, the bank could receive great benefits.

This fact is confirmed by the data contained in Table 2. Considering the methods of land acquisition by peasants through the mediation of the Peasant Land Bank in the period from 1884 to 1895, it can be seen that the most active peasants of the Penza province acquired land as part of rural societies. 14,567 dessiatines of land were acquired in this way. The total amount of the loans was 968,635 rubles. As part of the partnerships, almost 4 times less were purchased - 3,799 dessiatines, the size of the loans was 191,245 rubles, and only 45 dessiatines were purchased through the intermediary of the bank by individual peasants with a loan of 2,000 rubles, and this opportunity was used only in Saransk and Penza districts. Most of the land was acquired in the Gorodishchensky district - 4,800 dessiatines (26.1\% of the total for the province), followed by the Penza district, where 3,127 dessiatines (17.0\%) were 


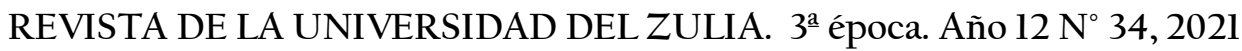
Roman V. Fedoseev et al.// Activities of the Peasant Land Bank in Penza province... 483-5ll DOI: http://dx.doi.org/10.46925//rdluz.34.27

purchased. Least of all, the peasants of the Kerensky district used the services of the bank, where only 28 dessiatines of land purchased as part of the partnership were laid. It is interesting that, in general, the peasants in Russia were more willing to buy out land as part of not rural societies, but partnerships. So, as part of the latter, they bought 1,417,493 dessiatines of land, with a total loan of 47,877,993 rubles. Whereas in the composition of rural communities there are 950,237 dessiatines of land and 33,421,500 rubles, respectively (see: Table 2).

Table 2. Ways of acquiring land by peasants through the mediation of the Peasant Land Bank in the Penza province in the period from 1884 to 1895 (Report of the Peasant Land Bank 1896).

\begin{tabular}{|l|c|c|c|c|c|c|}
\hline \multirow{2}{*}{ County } & \multicolumn{2}{|c|}{ Rural societies } & \multicolumn{2}{c|}{ Partnerships } & \multicolumn{2}{c|}{ Peasants } \\
\cline { 2 - 7 } & $\begin{array}{c}\text { Amount of } \\
\text { dessiatines } \\
\text { of land }\end{array}$ & $\begin{array}{c}\text { Loan } \\
\text { amount, } \\
\text { ruble }\end{array}$ & $\begin{array}{c}\text { Amount of } \\
\text { dessiatines } \\
\text { of land }\end{array}$ & $\begin{array}{c}\text { Loan } \\
\text { amount, } \\
\text { ruble }\end{array}$ & $\begin{array}{c}\text { Amount of } \\
\text { dessiatines } \\
\text { of land }\end{array}$ & $\begin{array}{c}\text { Loan } \\
\text { amount, } \\
\text { ruble }\end{array}$ \\
\hline Gorodischensky & 3582 & 150795 & 1218 & 19625 & 0 & 0 \\
\hline Insarsky & 2185 & 150365 & 168 & 9350 & 0 & 0 \\
\hline Kerensky & 0 & 0 & 28 & 1800 & 0 & 0 \\
\hline Krasnoslobodsky & 435 & 10000 & 0 & 0 & 0 & 0 \\
\hline Mokshansky & 1654 & 148660 & 372 & 22155 & 0 & 0 \\
\hline Narovchatsky & 1244 & 74650 & 0 & 0 & 0 & 0 \\
\hline Nizhnelomovsky & 546 & 44260 & 381 & 18850 & 0 & 0 \\
\hline Penza & 2595 & 243955 & 502 & 33675 & 30 & 1250 \\
\hline Saransk & 1680 & 87000 & 431 & 17890 & 15 & 750 \\
\hline Chembarsky & 646 & 58950 & 699 & 67900 & 0 & 0 \\
\hline $\begin{array}{l}\text { Total for the } \\
\text { province }\end{array}$ & 14567 & 968635 & 3799 & 191245 & 45 & 2000 \\
\hline Total for Russia & 950237 & 33421500 & 1417493 & 47877993 & 44214 & 1097067 \\
\hline
\end{tabular}

In a situation where one of the members of the corresponding society or partnership could not contribute their share of the funds, they were distributed among the other members, which had a negative impact on the development of economically active part of the peasants who were part of these collectives, causing a decline in interest in obtaining a loan as part of a particular group of peasants. "Large sums are issued on a mutual guarantee to a significant number of borrowers, sometimes not related to each other by anything except participation in the purchase, among which, therefore, very often disputes and troubles arise, making it difficult for the correct receipt of urgent payments. This inevitably entails the 
REVISTA DE LA UNIVERSIDAD DEL ZULIA. 3época. Año $12 \mathrm{~N}^{\circ}$ 34, 2021 Roman V. Fedoseev et al.// Activities of the Peasant Land Bank in Penza province... 483-51l DOI: http://dx.doi.org/10.46925//rdluz.34.27

confiscation of land by the bank and their sale at public auction" (Report of the Peasant Land Bank, 1889).

Among other things, the organization of the bank's activities was aimed at ensuring that it would resort to government assistance as little as possible. Accordingly, the loan issued for the initial expenses of the bank was repaid as soon as possible and in the future the bank could manage with its own funds. Based on this, the bank began to issue $5.5 \%$ of the certificate, and also set a fee of $1 \%$ for management costs. In addition, short periods were set for peasants to repay the debt (24.5 and 34.5 years), while payments were charged from 1 to $2 \%$ per year. Thanks to this, annual payments were $7.5 \%$ for a loan for 34.5 years and $8.5 \%$ for a loan for 24.5 years (Hertsenstein Nationalization, 1905). But despite the relative high cost of credit, the peasants began to actively buy up land through the bank. As can be seen from Table 1, 10,952 dessiatines of land were laid on the territory of the Penza province in 1884 and 1885 , which was $59.5 \%$ of the total number of dessiatines of land laid in the period from 1884 to 1895 ( 18,411 dessiatines). The total loan amount was 829,380 rubles, or $71.4 \%$ of the total amount of loans issued for the entire analyzed period of time (1,161,880 rubles). At the same time, the demand for credit here was much higher than in Russia as a whole, where in 1884 - 1885, 528,049 dessiatines of land were purchased through the intermediary of the bank, which amounted to $21.9 \%$ of 2,411,865 dessiatines of the total amount of land purchased in the period from 1883 to 1895 . The total loan amount was $23,291,347$ rubles, or $28.3 \%$ of the $82,359,684$ rubles issued in that period.

However, the negative consequences of an expensive loan and unjustified acquisition of land plots soon emerged. Many transactions turned out to be extremely unprofitable, due to which up to $15 \%$ of all loans were unviable, the peasants stopped cultivating the purchased land, despite the fact that they made additional payments when buying it. Payments were made irregularly, and the bank faced big problems in the sale of the remaining land on its balance sheet. As noted above, the growth of arrears began, and Penza province was one of the leaders in this indicator.

Under the influence of these unfavorable factors, mainly due to the fact that a large amount of property was transferred to the bank's ownership, views on peasant credit began to change (Zapariy Antoshin Strategies, 2020). However, the bank embarked on the path of curtailing its activities, instead of carefully examining the reasons for the massive 
REVISTA DE LA UNIVERSIDAD DEL ZULIA. 3época. Año $12 \mathrm{~N}^{\circ}$ 34, 2021 Roman V. Fedoseev et al.// Activities of the Peasant Land Bank in Penza province... 483-51l DOI: http://dx.doi.org/10.46925//rdluz.34.27

abandonment of land purchased through the bank, and immediately begin to lower payments (Hertsenstein Nationalization, 1905). In particular, in the period from 1887 to 1895 inclusively, 383 land plots from 120192 dessiatines of land, on which there was a capital debt in the amount of 6,914,655 rubles, came into the ownership of the bank from faulty borrowers, there were 27 such plots in the Penza province, the amount of land is 9,800 dessiatines, the amount of capital debt is 599,205 rubles (Report of the Peasant Land Bank, 1895).

Thus, the activities of the Peasant Land Bank on the territory of the Penza province in the period from 1884 to 1895 were carried out in the general course of the credit policy pursued by it on the territory of Russia, but had a certain specificity. Thus, the peasants of the province were more willing to take out loans for the purchase of land as part of rural societies, rather than partnerships, as was the case in the country as a whole. The high cost of credit led to the non-viability of many transactions and to an increase in arrears, as a result, to a reduction in the number of transactions. During the first period of the bank's activity on the territory of the Penza province, 81 loans were issued in the amount of 1,161,880 rubles, 18,410 dessiatines of land were pledged. At the same time, the volume of the bank's activities in the surveyed province was insignificant, accounting for only about $1 \%$ of the total volume of operations carried out by it in the country as a whole. With the help of the bank, the peasantry of the province acquired just over 18 thousand dessiatines of land, while according to official statistics in 1877 , all private land owners in the province owned 1,287,473 dessiatines, of which 53,854 dessiatines (Statistics of land tenure, 1905), were owned by peasants. Therefore, it becomes obvious that the Peasant Bank for the first 12 years of its activity on the territory of the province could not solve its goal - the development of land tenure among land-poor peasants. At the same time, it should be noted that the very fact of the creation of a specialized credit institution, whose activities were aimed at providing the peasantry with a soft loan for the purchase of land, thereby contributing to the reduction of land shortages among this class was of great importance.

The second period of the Peasant Bank's activity, as we have already noted, dates from 1896 to 1905, while the reform associated with giving the bank the opportunity to independently purchase land was caused by purely economic reasons. The agrarian crisis, aggravated in Russia in the early 1890s, forced the government to take measures to support 
REVISTA DE LA UNIVERSIDAD DEL ZULIA. 3é época. Año $12 \mathrm{~N}^{\circ}$ 34, 2021 Roman V. Fedoseev et al.// Activities of the Peasant Land Bank in Penza province... 483-5ll DOI: http://dx.doi.org/10.46925//rdluz.34.27

large landownership, giving it the opportunity, along with the already existing right of pledge of land in the Noble Bank, to sell part of its allotments to the Peasant Bank, which would help in making payments arrears on loans and support for their farm, while contributing to land provision for peasants who could subsequently acquire this land (Zak Peasant, 1911).

So, after the adoption of the Charter of 1895 (Charter of a peasant land bank, 1895), the second period of its activity began, the status of the Peasant Bank changed significantly. He received the right to buy land from his own capital for resale to the peasants. Moreover, it was essentially an "exclusive" right, because neither the Noble Land Bank, nor the jointstock land banks had such a right, only having the opportunity to keep on the balance sheet the lands of "faulty borrowers" that were not sold at auction. However, it should be noted that the bank already had the experience of acquiring land at its own expense: the bank acquired the Pesochensky estate in the Ryazan province in 1893, but this was a one-time case "on the basis of the Imperial command of August 26, 1893" (Report of the Peasant Land Bank, 1896).

The bank began to provide three types of loans from that moment: 1) loans secured by land purchased by peasants from private owners; 2) loans secured by land purchased from a bank; 3) loans secured by land purchased without the assistance of a bank. In addition, the new Charter, of 1895, provided the right to use the credit of the Peasant Land Bank to all bourgeois landowners living in rural areas, constantly engaged in agriculture (Charter of a peasant land bank, 1895). At the same time, the vast majority of the bank's clients continued to be peasants. From 1895 to 1905, the bank sold 626181.87 dessiatines of land, of the indicated amount of land sold to peasants 603259 dessiatines, which was 96.3\% of the total area of land sold (Proskuryakova Land, 1993).

Changes in the legal status of the Peasant Bank could not but affect the volume of its activities, which began to increase rather quickly. So, only 3 loans for the purchase of 573 dessiatines of land in the amount of 32,940 rubles were issued in 1896 in the Penza province. Just two years later, there were already 35 transactions, 11,824 dessiatines were purchased for the amount of 751,179 rubles, a little less in 1899 - 10,960 dessiatines of land for the amount of 781,506 rubles for 60 transactions. The bank issued even more loans in 1900 - 88, the size of the loan was 1,378,110 rubles, 18,461 dessiatines of land were purchased. The largest volume of transactions in the period from 1896 to 1905 was carried out by the bank in 1903, when 75 
REVISTA DE LA UNIVERSIDAD DEL ZULIA. 3época. Año $12 \mathrm{~N}^{\circ}$ 34, 2021 Roman V. Fedoseev et al.// Activities of the Peasant Land Bank in Penza province... 483-511 DOI: http://dx.doi.org/10.46925//rdluz.34.27

loans were issued, while 25,875 dessiatines of land were sold for the amount of $1,466,800$ rubles. In total, for the period from 1896 to 1905, 506 loans were issued in the province under consideration, 117,050 dessiatines of land were sold in the amount of 7,984,753 rubles. A significant increase in the volume of the bank's activities on the territory of the Penza province can be confirmed by the fact that in 1900 alone, the number of loans (88), their monetary equivalent (1,378,110 rubles) and the area of land sold (18,461 dessiatines) was greater than for the entire period from 1884 by 1895, when 81 loans were issued, 18,410 dessiatines of land were sold for an amount equal to 1,161,880 rubles (see: tables 1 and 3).

Similar trends were observed in the territory of Russia as a whole. The data in Table 3 recorded a constant growth in the volume of the bank's activity since 1896, the peak of which, as in the Penza province, in 1903, when 5,539 loans were issued in the amount of 60,044,054 rubles, while 739,581 dessiatines of land were sold. At the same time, the majority of loan agreements were concluded (6 385), and land was sold (817 365 dessiatins) in 1900, however, the amount of loans issued amounted to 53514814 rubles, which is almost 6.5 million rubles less than in 1903. In total, during the studied period of time, 5,864,329 dessiatines of land were sold through the intermediary of the bank and 45,257 loans were issued in the amount of 409,942,136 rubles (see: Table 5).

At the same time, the share of the province in question in the all-Russian indicators, although increased, continued to remain insignificant. For example, in 1900, only $0.4 \%$ of the total number of transactions, $2.2 \%$ of the land sold and $2.6 \%$ of the loan amount, in 1903 1.3\%, $3.5 \%$ and $2.4 \%$ respectively. In 1905 , i.e. at the end of the period under review $0.6 \%$ of the total number of transactions, $1.8 \%$ of the land sold and $1.6 \%$ of the total loan amount. In general, over 10 years of the second period, 1.2\% of all transactions carried out by the bank (506 out of 45,257), 1.2\% of the total amount of land sold with its assistance (117,050 out of $5,864,329$ dess.), Finally, 1, 9\% of the total loan amount (7,984,753 of 409,942,136 rubles). Thus, the statistical data presented in table 5 indicate that in the Penza province, the bank's activity after the reorganization has noticeably intensified, the volume of loans issued has increased significantly, the share of the province in the total scale of the studied credit institution has gradually increased (see: table 3). 
REVISTA DE LA UNIVERSIDAD DEL ZULIA. 3época. Año $12 \mathrm{~N}^{\circ}$ 34, 2021 Roman V. Fedoseev et al.// Activities of the Peasant Land Bank in Penza province... 483-5ll

DOI: http://dx.doi.org/10.46925//rdluz.34.27

Table 3. Loans issued by the Peasant Land Bank in Russia and the Penza province in the period from 1896 to 1905 (Report of the Peasant Land Bank 1896-1905).

\begin{tabular}{|c|c|c|c|c|c|c|}
\hline \multirow{2}{*}{ Years } & \multicolumn{3}{|c|}{ Penza province } & \multicolumn{3}{c|}{ Total across Russia } \\
\cline { 2 - 7 } & $\begin{array}{c}\text { Number } \\
\text { of loans }\end{array}$ & $\begin{array}{c}\text { Amount of } \\
\text { dessiatines } \\
\text { of land }\end{array}$ & $\begin{array}{c}\text { Loan } \\
\text { amount, } \\
\text { ruble }\end{array}$ & $\begin{array}{c}\text { Number of } \\
\text { loans }\end{array}$ & $\begin{array}{c}\text { Amount of } \\
\text { dessiatines } \\
\text { of land }\end{array}$ & $\begin{array}{c}\text { Loan amount, } \\
\text { ruble }\end{array}$ \\
\hline 1896 & 3 & 573 & 32940 & 1783 & 208658 & 7254782 \\
\hline 1897 & 9 & 1511 & 84454 & 2230 & 356314 & 20894698 \\
\hline 1898 & 35 & 11824 & 751179 & 3859 & 590229 & 36472530 \\
\hline 1899 & 60 & 10960 & 690920 & 5621 & 717386 & 44569437 \\
\hline 1900 & 88 & 18461 & 1378110 & 6385 & 817365 & 53514814 \\
\hline 1901 & 75 & 16995 & 1254180 & 5792 & 775251 & 54270422 \\
\hline 1902 & 74 & 13983 & 1085160 & 6056 & 695514 & 55737824 \\
\hline 1903 & 75 & 25875 & 1466800 & 5539 & 739581 & 60044054 \\
\hline 1904 & 66 & 9511 & 746790 & 4729 & 567628 & 46152170 \\
\hline 1905 & 21 & 7357 & 494220 & 3263 & 396403 & 31031405 \\
\hline Total & 506 & 117050 & 7984753 & 45257 & 5864329 & 409942136 \\
\hline
\end{tabular}

The increase in the volume of loans issued created the basis for a significant increase in prices for land purchased through the intermediary of the Peasant Bank. So, in 1896 in the Penza province the price was set at around 60 rubles per 1 dessiatine, and by 1905 it reached 85 rubles per l dessiatine, an increase of $29.5 \%$. At the same time, in Russia as a whole, a much more noticeable increase in prices was observed, from 1895 to 1905 the cost of 1 dessiatine of land purchased with the assistance of a bank more than doubled from 49 to 111 rubles (see: Table 4). Thus, the more the bank increased the volume of its activities, the more expensive it had to buy land for its clients. The increase in prices was influenced by both the preferential nature and ease of obtaining a loan, and the activities of the bank itself, because when applying for a loan, its size directly depended on the bank's assessment of the land plots against which the loan was issued. And although the bank began to publish the estimated statistics of land acquired with its assistance only since 1898, looking at the data in Table 5, one can see that the average valuation of land in the second period of its activity, as well as the purchase price, increased quite significantly, and it even was larger than the latter in 1898, 1899 and 1900 in the Penza province.

The opportunity given to the Peasant Bank to buy land from its own capital for resale to the peasants gave rise to a number of negative moments, since most of the land was acquired from the nobles and the bank was largely guided by their interests. So, for the period 
REVISTA DE LA UNIVERSIDAD DEL ZULIA. 3época. Año $12 \mathrm{~N}^{\circ}$ 34, 2021 Roman V. Fedoseev et al.// Activities of the Peasant Land Bank in Penza province... 483-5ll DOI: http://dx.doi.org/10.46925//rdluz.34.27

from 1893 (when the Pesochenskoye estate was acquired) and up to 1905, the bank purchased 504 estates in the amount of 961,487 dessiatines, while from the representatives of the "upper class" they bought 308 (61.1\%) estates in the amount of 660934 dessiatines of land (68.7\%) (Report of the Peasant Land Bank, 1883-1905). As F. Turner pointed out, "in most cases giving preference to the nobles over sellers belonging to other estates, the bank thereby sought to provide the nobles with the opportunity to sell economically weak estates, which, without such assistance from the bank, would be subject to unprofitable and often forced sale" (Turner State, 1901).

Table 4. Average price of 1 dessiatines of land purchased through the mediation of the Peasant Land Bank in the period from 1895 to 1905 (Report of the Peasant Land Bank 1900, 1905).

\begin{tabular}{|c|c|c|c|c|}
\hline \multirow{2}{*}{ Years } & \multicolumn{2}{|c|}{$\begin{array}{c}\text { Average purchase price of l dessiatines of } \\
\text { land (ruble) }\end{array}$} & $\begin{array}{c}\text { Average estimate of l dessiatines of } \\
\text { land (ruble) }\end{array}$ \\
\cline { 2 - 5 } & Penza province & European Russia & Penza province & $\begin{array}{c}\text { European } \\
\text { Russia }\end{array}$ \\
\hline 1896 & 60 & 49 & $\mathrm{n} / \mathrm{a}$ & $\mathrm{n} / \mathrm{a}$ \\
\hline 1897 & 64 & 71 & $\mathrm{n} / \mathrm{a}$ & $\mathrm{n} / \mathrm{a}$ \\
\hline 1898 & 69 & 76 & 74 & 72 \\
\hline 1899 & 71 & 78 & 78 & 72 \\
\hline 1900 & 85 & 83 & 86 & 76 \\
\hline 1901 & 85 & 91 & 83 & 81 \\
\hline 1902 & 92 & 108 & 87 & 93 \\
\hline 1903 & 67 & 108 & 64 & 93 \\
\hline 1904 & 98 & 112 & 89 & 95 \\
\hline 1905 & 85 & 111 & 78 & 96 \\
\hline
\end{tabular}

The purchase of unprofitable and loaned land began, for which there was no demand from other potential buyers, as well as land that, according to its economic characteristics, did not suit the peasants. So, A. N. Zak noted that "for owners of estates, especially those burdened with debts to land banks, this opportunity to sell their land directly into the hands of the Peasant Land Bank is sometimes very, very serious help: after all, there are not always buyers at all and peasants in particular; it is not uncommon for private buyers to refrain from entering into a transaction with the owner of the land, waiting either for the most unfavorable time for him or the moment of the forced sale of the owed estate, from public auctions for debts to banks" (Zak Peasant, 1911). 
REVISTA DE LA UNIVERSIDAD DEL ZULIA. 3época. Año $12 \mathrm{~N}^{\circ}$ 34, 2021 Roman V. Fedoseev et al.// Activities of the Peasant Land Bank in Penza province... 483-51l DOI: http://dx.doi.org/10.46925//rdluz.34.27

Thus, the second period of the Peasant Land Bank's activity in the Penza province was marked by a significant increase in both the total number of transactions (from 81 to 505), as well as the size of land acquired by peasants through its intermediary (from 18,410 dessiatines to 117,050 dessiatines) and, accordingly, the amount issued loans (1 161880 rubles to 7984 753 rubles). But along with an increase in the volume of loans issued, the number of estates remaining in the pledge of the bank, estates transferred to its balance sheet from non-payers, and, more importantly, there was a significant increase in land prices (from 1896 to 1905, an increase was $29.5 \%$ ), which hardly contributed to the growth of the well-being of the peasant population. But low interest rates (the maximum decrease dates back to 1898, when loan payments were lowered to $4 \%$ per year, both for loans already issued and for loans issued later) (On the reduction of payments 1898), as well as the availability of loans, right up to the beginning of agrarian unrest, nevertheless increased the demand for credit.

As noted above, with the adoption of the Manifesto of November 3, 1905 (On improving the welfare, 1905), the third stage of the activity of the Peasant Land Bank begins and this credit institution becomes an even more important instrument of the government's agrarian policy. As N. A. Proskuryakova justly noted: "The Peasant Land Bank occupied a special place in the system of land credit. This was determined by the role he played in the government's attempts to solve the peasant question. After the beginning of agrarian unrest, a gradual transition from a passive instrument of conservation of the existing system of land relations in the 80-90s of the 19th century to active intervention in the process of mobilizing land ownership at the beginning of the 20th century began" (Proskuryakova Land, 1993).

The reasons for the significant reorganization of the bank, in our opinion, were aptly noted by A. N. Zak, who wrote that "If before the main motivation for the sale of land were purely economic reasons, now it is joined here, and sometimes displaces the rest, a political motive. It is precisely the fear of the possibility of complete expropriation, the hope to appease the peasants, partially satisfying their hunger for land and, finally, the desire of the landowners to use the moment to sell the land before it's too late" (Zak Peasant, 1911).

At the same time, changes in the legal status of this credit institution were not limited only to the Manifesto of 1905, during 1906 another 14 different legalizations and orders were issued regarding its activities. The main changes concerned the following: on March 21, the Peasant Bank, along with the Noble Bank, stopped issuing loans in cash, replacing them with 
REVISTA DE LA UNIVERSIDAD DEL ZULIA. 3época. Año $12 \mathrm{~N}^{\circ}$ 34, 2021 Roman V. Fedoseev et al.// Activities of the Peasant Land Bank in Penza province... 483-51l DOI: http://dx.doi.org/10.46925//rdluz.34.27

the issuance of mortgage sheets (On changing the grounds, 1900); On April 26, the bank in question was granted the right to take over debts on the estates mortgaged in the State Noble land and joint-stock land banks, with the release of the corresponding estates from the pledge to the indicated credit institutions (On granting the Peasant Land Bank 26.04.1906); On August 30, the right of the Peasant Bank to take on debts on estates mortgaged in other credit institutions was extended to the Special Department of the State Noble Land Bank, to which the affairs of the Mutual Land Credit Society, liquidated in 1890, were transferred (On granting the Peasant Land Bank 08.30.1906); On November 15, perhaps the most important decree followed, granting the Peasant Bank the right to issue loans on the security of allotments. The decree was adopted "in view of the forthcoming, from January 1, 1907, the release of allotment lands from the redemption debt lying on them" (which was established by the Manifesto of 1905). As expected, "with the prudent use of the new type of state credit provided to the peasants, this measure will make it easier for them to obtain the funds necessary for expanding land tenure and improving land use". The loan was issued "to cover the costs of land use improvements: a) during the transition from communal ownership to household property, b) during the resettlement of societies into separate settlements or farms" (On the issuance of loans, 1906), c) when individual householders were assigned to one place, this greatly contributed to the achievement of the goal of the Stolypin reforms the transition from communal land ownership to household land ownership, at the same time creating a basis for increasing the number of loans issued by the bank. Since the main clients were not rural societies and associations, but individual householders who had the opportunity to obtain a loan on the security of their allotment lands.

So, initially, the main task underlying the activities of the Peasant Land Bank was to assist peasants in acquiring land plots offered for sale, which is why the bank's operations were limited to issuing loans for the purchase of land by peasants under a voluntary agreement with individuals and various institutions. Subsequently, the bank was allowed to issue loans secured by the land plots acquired by the peasants without its assistance, to pay off the debts arising from the purchase of this land. Further, the bank was given the right to buy estates at its own expense, with a view to their subsequent resale to peasants. Finally, the decree of November 15, 1906, allowed the issuance of loans to peasants on the security of allotments. 
REVISTA DE LA UNIVERSIDAD DEL ZULIA. 3época. Año $12 \mathrm{~N}^{\circ}$ 34, 2021 Roman V. Fedoseev et al.// Activities of the Peasant Land Bank in Penza province... 483-51l DOI: http://dx.doi.org/10.46925//rdluz.34.27

Thus, from the end of 1906, the Bank's lending operations were divided into the following categories: 1) loans issued on the security of land plots purchased by peasants from private owners and various institutions; 2) loans secured by land plots acquired from estates owned by the bank; 3) loans secured by land plots purchased without the assistance of a bank 4) loans secured by allotment land (Report of the Peasant Land Bank, 1906).

Considering all of the above, as well as the fact that the Decree, adopted on November 3,1905 , removed the restrictions on the size of the bank's equity capital (On facilitating the task, 1905). From 1907, the scale of its activities will begin to increase. This circumstance can be confirmed statistically by analyzing Table No. 5. Unfortunately, the report for 1907 at our disposal does not contain the provincial data, but even without this we can clearly see the dynamics towards an increase in indicators up to 1910, when the volume of the bank's activities in the territory Penza Governorates reach their maximum value not only during this period, but also for the entire period of its operation. So, if in 190629 loans were issued in the province, then after two years 1 144, in 1910 - 4824 (for comparison, only 586 loans were issued in the first two periods of the bank's activity in the Penza province). The sharp increase in this indicator is associated, first of all, with the reorientation of the bank to issue loans to individual householders, and not to societies and associations of peasants.

As for the amount of land sold on a loan, as well as the volume of lending, there was also a significant increase, so in 1906 peasants purchased 13,469 dessiatines of land through the intermediary of a bank, the loan amount was 1,415,300 rubles, which is not much different from the indicators of the previous period. But already in 1908, these indicators surpassed those for any separately taken year of the previous two periods: 36,770 dessiatines of land were sold, the loan amount was 4,388,920 rubles. In 1909-1910, 78696 and 79636 dessiatines of land were sold through the provision of a loan, 9321970 and 9845220 rubles were issued on credit, respectively. In the future, there is a decline in indicators, reaching their usual values by the beginning of the First World War. In general, for the third period, the Penza branch of the bank issued 13,137 loans in the amount of 33,086,729 rubles secured by 282,891 dessiatines of land. Considering that in 1905 the peasants of the province owned only 118,156 dessiatines out of 1,264,091 dessiatines of privately owned land (Statistics of land tenure in, 1905), it becomes obvious that during the third period of its activity the Peasant Bank became the main instrument for solving the land issue. 
REVISTA DE LA UNIVERSIDAD DEL ZULIA. 3época. Año $12 \mathrm{~N}^{\circ}$ 34, 2021 Roman V. Fedoseev et al.// Activities of the Peasant Land Bank in Penza province... 483-51l DOI: http://dx.doi.org/10.46925//rdluz.34.27

Similar trends were observed in the all-Russian scale of the activity of the credit institution under consideration. Since 1906, a fairly significant increase in all indicators has been recorded, which, since 1908, significantly exceed the indicators of previous decades. At the same time, in percentage terms, the share of the Penza province in the all-Russian indicators has increased quite significantly. So, in 1910, when the size of the bank's activities reached its maximum, in the province under consideration, $6.9 \%$ of the total number of transactions were concluded, $5.1 \%$ of the total amount of land sold by the bank was sold and $5.8 \%$ of the total amount was issued. issued loans. In general, from 1906 to 1915 on the territory of Russia, the bank issued 337,848 loans, sold 9,461,003 dessiatines of land to peasants, the total amount of the issued loan capital amounted to 1,026,033,849 rubles. The contribution of the Penza province to the total "piggy bank" amounted to 3.9\% of the number of loans issued, 3.0\% of the amount of land sold through the bank, 3.2\% of the amount of loans issued (see: Table 5).

At the same time, during this period the negative aspects of the bank's activities were most clearly manifested. First of all, even greater inflation of land prices, if in the second period of the Peasant Bank's activity the maximum price of 1 dessiatines of land in Penza province reached 98 rubles, and in Russia as a whole 112 rubles, which was recorded in 1904 (see: Table 4). Already in 1908, the cost was equal to 130 rubles / dessiatines in the province under study and 116 rubles / dessiatines throughout the territory of the bank's activity (Report of the Peasant Land Bank, 1908), and in 1910 - 132 rubles / dessiatines and 136 rubles / dessiatines, respectively (Report of the Peasant Land Bank, 1910). Such a strong rise in prices was largely due to speculative manifestations in the land market, when the purchase and sale of land was carried out not for the sake of increasing peasant land ownership, but for the benefit derived from the difference between the prices at which land was acquired and alienated.

In addition, a sharp increase in the volume of the bank's activities in the third period led to an increase in the number of estates that passed into its ownership from non-payers. So, on January 1, 1906, 114 estates remained on the bank's balance sheet, transferred to it from defective borrowers, which included 60,662 dessiatines of land and the remainder of the capital debt in the amount of 3,657,397 rubles (in the Penza province 2 estates, 1,088 dessiatines of land and 95458 rubles of debt) (Report of the Peasant Land Bank, 1905). In 
1906, 217 land plots with 51,550 dessiatines of land and 3,490,713 rubles of capital debt (4 plots, 2,735 dessiatines, 194,364 rubles of debt in the territory of the Penza branch) were transferred to the bank from non-payers (Report of the Peasant Land Bank, 1906). In general, for the period from 1906 to 1915, the indicators are even more impressive: on the territory of Russia, 5,198 loans with 415,773 dessiatines of mortgaged land and the amount of capital debt equal to 33,683,660 rubles turned out to be unviable. Moreover, the share of the Penza province in the all-Russian indicators was quite significant: $9.9 \%$ of the total number of loans (517 out of 5,198), 3.4\% of all land transferred to the bank (14,290 out of 415,773 dessiatines), $4.5 \%$ of the amount capital debt $(1,526,200$ out of 33,683,660 rubles) (Report of the Peasant Land Bank, 1906-1915). Such a sharp increase in the number of defective borrowers' estates transferred to the bank's ownership can be explained by a number of socio-economic reasons. First of all, these are agrarian unrest and the subsequent reorientation of the bank to issue loans to individual clients. If earlier loans were issued to societies or partnerships, which could include several dozen peasants, but such a collective was counted as one loan, then since 1906 each householder was counted separately. In the second - the beginning of the First World War, as a result - a significant increase in insolvency.

Table 5. Loans issued by the Peasant Land Bank in Russia and the Penza province in the period from 1906 to 1915 (Report of the Peasant Land Bank 1906-1915).

\begin{tabular}{|c|c|c|c|c|c|c|}
\hline \multirow[b]{2}{*}{ Years } & \multicolumn{3}{|c|}{ Penza province } & \multicolumn{3}{|c|}{ Total across Russia } \\
\hline & $\begin{array}{l}\text { Number } \\
\text { of loans }\end{array}$ & $\begin{array}{c}\text { Amount of } \\
\text { dessiatines } \\
\text { of land }\end{array}$ & $\begin{array}{c}\text { Loan amount, } \\
\text { ruble }\end{array}$ & $\begin{array}{l}\text { Number } \\
\text { of loans }\end{array}$ & $\begin{array}{c}\text { Amount of } \\
\text { dessiatines } \\
\text { of land }\end{array}$ & $\begin{array}{c}\text { Loan amount, } \\
\text { ruble }\end{array}$ \\
\hline 1906 & 29 & 13469 & 1415300 & 3115 & 522751 & 54309290 \\
\hline 1907 & $\mathrm{n} / \mathrm{a}$ & $\mathrm{n} / \mathrm{a}$ & $\mathrm{n} / \mathrm{a}$ & 5379 & 932849 & 107831578 \\
\hline 1908 & 1144 & 36770 & 4388920 & 19377 & 1019014 & 116283714 \\
\hline 1909 & 4191 & 78696 & 9321970 & 50719 & 1227114 & 144497534 \\
\hline 1910 & 4824 & 79636 & 9845220 & 69710 & 1549720 & 169558320 \\
\hline 1911 & 1693 & 36426 & 4013080 & 65327 & 1397637 & 147327586 \\
\hline 1912 & $418 \mathrm{e}$ & 12629 & 1299299 & 43933 & 917313 & 97139333 \\
\hline 1913 & 371 & 11005 & 1239850 & 40107 & 894141 & 92000030 \\
\hline 1914 & 269 & 8142 & 851090 & 27967 & 673946 & 68274773 \\
\hline 1915 & 198 & 6118 & 712000 & 12214 & 326518 & 28811691 \\
\hline Total & 13137 & 282891 & 33086729 & 337848 & 9461003 & 1026033849 \\
\hline
\end{tabular}


REVISTA DE LA UNIVERSIDAD DEL ZULIA. 3época. Año $12 \mathrm{~N}^{\circ}$ 34, 2021 Roman V. Fedoseev et al.// Activities of the Peasant Land Bank in Penza province... 483-51l DOI: http://dx.doi.org/10.46925//rdluz.34.27

In general, for the period from 1884 to 1915 on the territory of the Penza province, the Peasant Bank issued 13,723 loans, secured by the 418,351 dessiatines of land sold to the peasants, the amount of loans issued in this case was equal to 42,233,362 rubles, which amounted to 3.4\% of the total the number of loans issued in Russia $(398,030), 2.3 \%$ of all land sold through the bank (17,737,197 dess.), 2.8\% of the total amount of loans issued (1,518,335,669 rubles). The least activity of the bank was observed in the first period of its activity, when only 81 loans were issued, which amounted to $0.6 \%$ of their total number, 18,410 dessiatines of land or $4.4 \%$ of its total volume were sold to peasants for the entire study period, finally, the size of the loans was only 1,161,880 rubles, or $2.7 \%$ of their total amount. We see similar indicators in Russia as a whole, so during the first period of the bank's operation, 14,925 loans were issued (3.7\% of their total for the entire time), the bank's clients, with its assistance, purchased 2,411,865 dessiatines of land (13.6\% of its total volume), the amount of money issued was 82 359684 rubles. (5.4\% of their total). The second period is characterized by an increase in the number of transactions, in particular, on the territory of the province, the bank issued 505 loans (3.6\% of their total number), the object of the bank's operations was 117,050 dessiatines of land (27.3\% of its total number), the amount of loans issued amounted to 7984753 rubles (18.9\% of the total for the 32-year period of activity). Nevertheless, the largest volume of the bank's activities falls on the third period, when from a largely passive tool for the development of land ownership among land-poor peasants, it moved to active intervention in the processes of redistribution of land ownership. From 1906 to 1915, the Penza branch of the bank issued 13,137 loans (95.7\% of their total number), in the amount of 33,086,729 rubles ( $78.3 \%$ of their total amount) secured by 282,891 dessiatines of land (67.6\% of its total size). Almost $4 / 5$ of all the bank's activity fell on the last period of its activity (see: Table 6).

Table 6. Loans issued by the Peasant Land Bank in Russia and the Penza province in the periods 1883-1895, 1896-1906, 1907-1915 (Report of the Peasant Land Bank 1983-1915).

\begin{tabular}{|c|c|c|c|c|c|c|}
\hline \multirow{2}{*}{ Periods } & \multicolumn{3}{|c|}{ Penza province } & \multicolumn{3}{c|}{ Total across Russia } \\
\cline { 2 - 7 } & $\begin{array}{c}\text { Number } \\
\text { of loans }\end{array}$ & $\begin{array}{c}\text { Amount of } \\
\text { dessiatines } \\
\text { of land }\end{array}$ & $\begin{array}{c}\text { Number of } \\
\text { loans }\end{array}$ & $\begin{array}{c}\text { Amount of } \\
\text { dessiatines } \\
\text { of land }\end{array}$ & $\begin{array}{c}\text { Number of } \\
\text { loans }\end{array}$ & $\begin{array}{c}\text { Amount of } \\
\text { dessiatines of } \\
\text { land }\end{array}$ \\
\hline $1883-1895$ & 81 & 18410 & 1161880 & 14925 & 2411865 & 82359684 \\
\hline $1896-1905$ & 505 & 117050 & 7984753 & 45257 & 5864329 & 409942136 \\
\hline $1906-1915$ & 13137 & 282891 & 33086729 & 337848 & 9461003 & 1026033849 \\
\hline $\begin{array}{c}\text { Total 1883- } \\
1915\end{array}$ & 13723 & 418351 & 42233362 & 398030 & 17737197 & 1518335669 \\
\hline
\end{tabular}


REVISTA DE LA UNIVERSIDAD DEL ZULIA. $3^{a}$ época. Año $12 \mathrm{~N}^{\circ} 34,2021$ Roman V. Fedoseev et al.// Activities of the Peasant Land Bank in Penza province... 483-51l DOI: http://dx.doi.org/10.46925//rdluz.34.27

Conclusion

Thus, the creation and operation of the Peasant Land Bank was an element of the government's agrarian policy. On the one hand, it was aimed at creating peasant land tenure by providing loans to buy land from private owners, and on the other hand, it was aimed at maintaining large land tenure through the intermediary function of selling surplus land property. After the reorganization of the bank in 1895, it was through the direct purchase of land by the bank from private individuals, of course, primarily from landowners. In the first two periods of its operation, the bank took a rather passive position. This was due to statutory restrictions, at first performing only an intermediary function, and then being limited in the amount that he could spend on the purchase of estates (only 50 million rubles). To a greater extent, meeting the needs of large landownership, which, after the reforms of the 1860s, could not fully adapt to the new economic conditions and was forced to give up a significant part of its land ownership, in connection with which the bank had an important national economic importance, softening the most acute moments of mobilization processes taking place in the land market. At the same time, the bank did not solve the tasks set before it until the beginning of the agrarian unrest of 1905-1907, because the volume of its activities at best compensated for the natural increase among the peasant population. The main reason for this was that the bank's activities were almost exclusively aimed at meeting the needs of large landowners, often even to the detriment of the interests of the peasantry, and all the main reforms in its activities were based on the economic interests of the local nobility.

A radical change in agrarian policy in general and in approaches to the organization and activities of the Peasant Bank took place at the beginning of the Stolypin reform, when the government became concerned about the development of strong individual peasant farms, the destruction of the community began, attempts were made to modernize land use methods, including through an active credit policy. The reason for such active, mostly correct measures was the crisis of peasant land tenure and the unresolved land issue, which led to peasant unrest and demanded an immediate response from the government. In this connection, the role of the bank in the implementation of agricultural policy has increased many times, as well as the volume of its operations.

The bank's activities on the territory of the Penza province did not differ in significant volumes and peculiarities, accounting for in the first period of its activity only $0.5 \%$ of the 
REVISTA DE LA UNIVERSIDAD DEL ZULIA. 3é época. Año $12 \mathrm{~N}^{\circ}$ 34, 2021 Roman V. Fedoseev et al.// Activities of the Peasant Land Bank in Penza province... 483-5ll DOI: http://dx.doi.org/10.46925//rdluz.34.27

total number of loans issued to it on the territory of Russia, $0.8 \%$ of all land pledged in the bank and $1.4 \%$ of the total loan amount. In the second period, the activity of the credit institution under consideration in the Penza Territory slightly increased, which resulted in an increase in its share in all-Russian indicators: $1.2 \%$ of all transactions carried out by the bank, $1.2 \%$ of the total amount of land sold with its assistance, $1,9 \%$ of the total loan amount. But the province made the greatest contribution during the third period, when the volume of activities of the Penza branch amounted to $3.9 \%$ of the total number of loans issued by the bank, $3.0 \%$ of the amount of land sold through the bank and 3.2\% of the total amount of loans provided. In general, for the entire period of operation of the Peasant Land Bank on the territory of the Penza province, 13,723 loans were issued to them, 418,351 dessiatines of land were sold to peasants, the total amount of lending was 42,233,362 rubles, in percentage terms, this was 3.4\% of the total amount loans issued in Russia, $2.3 \%$ of all land sold through the intermediary of the bank, $2.8 \%$ of the total amount of loans issued.

\section{References}

Charter of a peasant land bank from 27.11.(1895). PSZ-III. T. XV. No. 12195.

Fedoseev R.V., Mariskin O.I., Bogatyrev E.D. (2019) The Crisis of Noble Land Ownership in the second half of 19th - early 20th century (Based on Materials from the Middle Volga Region). Amazonia Investiga. Vol. 8, Núm. 20. P. 104-114.

Frolov S.A. (2004). Mortgage of land in the Tambov province in 1884 - 1917 (on the example of the activities of the peasant and noble banks): PhD Dissertation. Tambov, 2004.257 p.

Hertsenstein M.Ya. (1905). Nationalization of the land. Peasant bank and redemption operation. St. Petersburg: Publication of the Public Benefit Partnership, 190 p.

On changing the grounds (1900)... On changing the grounds for issuing loans from the State Noble Land and Peasant Land Banks: the Imperially approved opinion of the State Council of 03/21/1900. PSZ-III. T XXVI. No. 27584.

On facilitating the task (1905)... On facilitating the task of the Peasant Land Bank to assist in increasing the area of land ownership of land-poor peasants: The Imperial Decree given to the Senate of 03.11.1905. PSZ-III. T. XXV. No. 26873.

On granting the Peasant Land Bank (1906)... On granting the Peasant Land Bank, in the course of operations on land pledged in the State Noble Land and Joint-Stock Land Banks, to assume debts to the aforementioned credit institutions: The highest approved opinion of the State Council dated 26.04.1906. PSZ-III. T XXVI. No. 27826. 
REVISTA DE LA UNIVERSIDAD DEL ZULIA. 3é época. Año $12 \mathrm{~N}^{\circ}$ 34, 2021 Roman V. Fedoseev et al.// Activities of the Peasant Land Bank in Penza province... 483-5ll DOI: http://dx.doi.org/10.46925//rdluz.34.27

On granting the Peasant Land Bank (1906) ...On granting the Peasant Land Bank, in the course of operations on land pledged in the Special Department of the State Noble Land Bank, to take over debts to the aforementioned credit institution: The highest approved regulation of the Council of Ministers dated 08.30.1906. PSZ-III. T XXVI. No. 28322.

On improving the welfare (1905) ...On improving the welfare and alleviating the situation of the peasant population: Manifesto of 03.11.1905. PSZ-III. T. XXV. No. 26871.

On the addition of some (1906) ...On the addition of some provisions of the current law relating to peasant land tenure and land use: the Imperial decree of 09.1l.1906. PSZ-III. T. XXVI. No. 28528.

On the all-merciful granting (1861) ... On the all-merciful granting to serfs of the rights of the state of free rural inhabitants, and on the structure of their life: Manifesto of 02.19.1861. PSZII. T. XXXVI. No. 36650.

On the issuance of loans (1906) ...On the issuance of loans by the Peasant Land Bank on the security of allotment land: the Personalized Imperial Decree given to the Governing Senate of 11/15/1906. PSZ-III. T XXVI. No. 28547.

On the most mercifully (1894) ...On the most mercifully bestowed mercies and reliefs on the occasion of the marriage of His Imperial Majesty, Sovereign Emperor Nikolai Alexandrovich: Manifesto of 11/14/1894. PSZ-III. T. XIV. No. 11035.

On the procedure for the commission (1883) ...On the procedure for the commission of serf acts for the purchase of land acquired with the assistance of the Peasant Land Bank: The highest approved opinion of the State Council of March 22, 1883. PSZ-III. T. III. No. 1453.

On the reduction of payments (1898) ...On the reduction of payments by borrowers of the Peasant Land Bank: the Imperial Decree given to the Minister of Finance dated 06.12.1898. PSZ-III. T. XVIII. No. 16161.

Proskuryakova N. A. (1993). Land loan and bourgeois-agrarian evolution of Russia in the late 19th - early 20th centuries: PhD Dissertation. Moscow,.434 p.

Regulations on the peasants (1861) ...Regulations on the peasants who emerged from serfdom on 19.02.1861. PSZ-II. T. XXXVI. No. 36657.

Regulations on the peasant (1882) ....Regulations on the peasant land bank dated 05/18/1882. PSZ-III. T. II. No. 894.

Report of the Peasant Land Bank for (1883). St. Petersburg: Printing house of I.S. Levy, $1884.83 \mathrm{p}$.

Report of the Peasant Land Bank for (1884). St. Petersburg: Printing house of I.S. Levy, $1885.198 \mathrm{p}$.

Report of the Peasant Land Bank for (1885). St. Petersburg: Printing house of P.P. Soykin, $1886.259 \mathrm{p}$. 
REVISTA DE LA UNIVERSIDAD DEL ZULIA. 3é época. Año $12 \mathrm{~N}^{\circ}$ 34, 2021 Roman V. Fedoseev et al.// Activities of the Peasant Land Bank in Penza province... 483-51l DOI: http://dx.doi.org/10.46925//rdluz.34.27

Report of the Peasant Land Bank for (1886). St. Petersburg: Printing house of P.P. Soykin, $1887.237 \mathrm{p}$.

Report of the Peasant Land Bank for (1887). St. Petersburg: Printing house of P.P. Soykin, $1889.245 \mathrm{p}$.

Report of the Peasant Land Bank for (1888). St. Petersburg: Printing house of P.P. Soykin, $1889.231 \mathrm{p}$.

Report of the Peasant Land Bank for (1889). St. Petersburg: Printing house of P.P. Soykin, $1890.68 \mathrm{p}$.

Report of the Peasant Land Bank for (1890). St. Petersburg: Printing house of P.P. Soykin, $1891.124 \mathrm{p}$.

Report of the Peasant Land Bank for (1891). St. Petersburg: Printing house of Prince V.P. Meshcheroky, 1892.196 p.

Report of the Peasant Land Bank for (1892). St. Petersburg: Printing house of Prince V.P. Meshcheroky, 1893.194 p.

Report of the Peasant Land Bank for (1893). St. Petersburg: Printing house of Prince V.P. Meshcheroky, 1894.275 p.

Report of the Peasant Land Bank for (1894). St. Petersburg: Printing house of Prince V.P. Meshcheroky, 1895.286 p.

Report of the Peasant Land Bank for (1895). St. Petersburg: Printing house of Prince V.P. Meshcheroky, $1896.436 \mathrm{p}$.

Report of the Peasant Land Bank for (1896). St. Petersburg: Printing house of Prince V.P. Meshcheroky, 1898.494 p.

Report of the Peasant Land Bank for (1898). St. Petersburg: Partnership "Printing House of S. P. Yakovlev", 1899.270 p.

Report of the Peasant Land Bank for (1899). St. Petersburg: Partnership "Printing House of S. P. Yakovlev", 1900. 285 p.

Report of the Peasant Land Bank for (1900). St. Petersburg: Partnership "Printing House of S. P. Yakovlev", 1901.370 p.

Report of the Peasant Land Bank for (1901). St. Petersburg: "Printing House of S. P. Yakovlev", 1902. $401 \mathrm{p}$.

Report of the Peasant Land Bank for (1902). St. Petersburg: "Printing House of S. P. Yakovlev", 1904. $470 \mathrm{p}$.

Report of the Peasant Land Bank for (1903). St. Petersburg: "Printing House of S. P. Yakovlev", 1905. 424 p. 
REVISTA DE LA UNIVERSIDAD DEL ZULIA. 3é época. Año $12 \mathrm{~N}^{\circ}$ 34, 2021 Roman V. Fedoseev et al.// Activities of the Peasant Land Bank in Penza province... 483-51l DOI: http://dx.doi.org/10.46925//rdluz.34.27

Report of the Peasant Land Bank for (1904). St. Petersburg: "Printing House of S. P. Yakovlev", 1906. 403 p.

Report of the Peasant Land Bank for (1905). St. Petersburg: "Printing House of S. P. Yakovlev", 1907. 478 p.

Report of the Peasant Land Bank for (1906). St. Petersburg: "Printing House of S. P. Yakovlev", 1908. 614 p.

Report of the Peasant Land Bank for (1907). St. Petersburg: "Printing House of S. P. Yakovlev", $1909.93 \mathrm{p}$.

Report of the Peasant Land Bank for (1908). St. Petersburg: "Printing House of S. P. Yakovlev", 1910. 271 p.

Report of the Peasant Land Bank for (1909). St. Petersburg: "Printing House of S. P. Yakovlev", 1910. 274 p.

Report of the Peasant Land Bank for (1910). St. Petersburg: "Printing House of S. P. Yakovlev", 1911. $278 \mathrm{p}$.

Report of the Peasant Land Bank for (1911). St. Petersburg: "Printing House of S. P. Yakovlev", 1912. $297 \mathrm{p}$.

Report of the Peasant Land Bank for (1912). St. Petersburg: "Printing House of S. P. Yakovlev", 1913. $256 \mathrm{p}$.

Report of the Peasant Land Bank for (1913). Petrograd: "Printing House of S. P. Yakovlev", 1914. $242 \mathrm{p}$.

Report of the Peasant Land Bank for (1914). Petrograd: "Printing House of S. P. Yakovlev", 1915. $243 \mathrm{p}$.

Report of the Peasant Land Bank for (1915). Petrograd: "Printing House of S. P. Yakovlev", 1916. $242 \mathrm{p}$.

Richter D.I. (1917). Agrarian issues in Russia. Issue II. State land banks in Russia and their further destiny. Petrograd: V.F. Kirshbaum,28 p.

Ruziyeva E. A., Nurgaliyeva A. M., Duisenbayeva B. B., Assanova A. B., Shtiller M. V. (2019). Analysis of investments role in the economic development // Bulletin of National academy of sciences of the Republic of Kazakhstan. Vol. 2, N 378. P. 189-198. https://doi.org/10.32014/2019.2518-1467.55

State Archives of the Penza Region (hereinafter referred to as GAPO). F. 15. Op. 1.

Statistics of land tenure in (1905). Issue 22. Penza province. St. Petersburg: Publishing house TsSK MVD, 1906. 
REVISTA DE LA UNIVERSIDAD DEL ZULIA. 3é época. Año $12 \mathrm{~N}^{\circ}$ 34, 2021 Roman V. Fedoseev et al.// Activities of the Peasant Land Bank in Penza province... 483-511 DOI: http://dx.doi.org/10.46925//rdluz.34.27

Turner F. State and land tenure (1901). Part II. Peasant land tenure. St. Petersburg: V.F. Kirshbaum,434 p.

Zak A.N. (1911). Peasant land bank. 1883 - 1910. Moscow: Association of short-term printing A.A. Levenson.619 p.

Zapariy Yu., Antoshin A. (2020). Strategies and devices of Russian politics: history and modernity. Quaestio Rossica. Vol. 8, No 2. Pp. 341-352. https://doi.org/10.15826/qr.2020.2.466 